\title{
PERBEDAAN ASUPAN PROTEIN, ZAT BESI, ASAM FOLAT, VITAMIN B12 DAN KEJADIAN ANEMIA PADA IBU NIFAS YANG MELAKUKAN MUTIH DAN TIDAK MELAKUKAN MUTIH DI KECAMATAN GEBOG, KABUPATEN KUDUS
}

\author{
Titien Indah Saputri, Hartanti Sandi Wijayanti*) \\ Program Studi Ilmu Gizi Fakultas Kedokteran Universitas Diponegoro \\ J1.Dr.Sutomo No.18, Semarang, Telp (024) 8453708, Email : gizifk@ undip.ac.id
}

\begin{abstract}
Background: Mutih was a food taboo practiced among postpartum women at Gebog, Kudus, that eating only rice, tempeh, tofu, and several vegetables and fruits. Inadequate intake and food variation caused postpartum women at risk of protein, iron, folate, and vitamin $B 12$ deficiency. It could be a risk factor of postpartum anemia.

Objective: The aim of this study was to analyze the difference of protein, iron, folate, vitamin B12 and anemic status between postpartum women practicing mutih and not practicing mutih.

Metode: This research was observational study with cross sectional approach. The subjects of this study consisted of 16 postpartum women practicing mutih and 16 postpartum women not practicing mutih, which were taken by purposive sampling. Nutrient intakes were obtained by using Semiquantitative Food Frequency Questionaire and hemoglobin level was measured by cyanmethemoglobin method. Difference of hemoglobin level between two groups was analyzed by independent $t$-test, and difference of nutrient intakes, including protein, iron, folate, and vitamin B12 were analyzed by Mann-Whitney test.

Results: The results showed that 93,7\% of postpartum women practicing mutih were anemic, while only $25 \%$ of postpartum women not practicing mutih were anemic. There were significant differences of anemic status $(p<0.01)$, protein intake $(p<0.01)$, and vitamin B12 intake $(p<0.01)$ between postpartum women practicing mutih and not practicing mutih. There were no significant differences of iron and folate intake between postpartum women practicing mutih and not practicing mutih $(p=0.07$ and $p=0.19)$. Both groups had inadequate protein, iron, folate, and vitamin B12 intake.
\end{abstract}

Conclusion: There were differences of protein, vitamin B12 intake, and anemic status between postpartum women practicing mutih and not practicing mutih.

Key Words: Mutih, nutritional intake, hemoglobin level, anemic status, postpartum women

\section{ABSTRAK}

Latar Belakang: Mutih merupakan budaya pantang makan yang dilakukan ibu nifas dengan hanya mengkonsumsi nasi, tempe, tahu, beberapa jenis sayur dan buah. Rendahnya jumlah asupan dan variasi makanan menyebabkan ibu nifas berisiko mengalami defisiensi protein, zat besi, asam folat, dan vitamin B12. Hal tersebut dapat menjadi faktor risiko terjadinya anemia gizi pada ibu nifas.

Tujuan: Menganalisis perbedaan asupan protein, zat besi, asam folat, vitamin B12, dan kejadian anemia pada ibu nifas mutih dan tidak mutih.

Metode: Penelitian ini merupakan penelitian observasional dengan desain cross sectional. Jumlah sampel terdiri dari 16 ibu nifas mutih dan 16 ibu nifas tidak mutih. Pemilihan subjek penelitian dengan purposive sampling. Asupan zat gizi diperoleh dari Semiquantitative Food Frequency Questionaire dan kadar hemoglobin diukur menggunakan metode cyanmethemoglobin. Perbedaan kadar hemoglobin diuji menggunakan uji independent t-test, dan asupan zat gizi, meliputi protein, zat besi, asam folat, dan vitamin B12 menggunakan uji Mann-Whitney.

Hasil: . Kejadian anemia pada ibu nifas mutih sebesar 93,7\%, sedangkan pada ibu nifas tidak mutih hanya sebesar $25 \%$. Terdapat perbedaan bermakna asupan protein ( $p<0.01)$, vitamin B12 ( $p<0.01)$, dan kejadian anemia $(p<0.01)$ antara ibu nifas mutih dan tidak mutih. Tidak terdapat perbedaan bermakna asupan zat besi dan asam folat antara ibu nifas mutih dan tidak mutih ( $p=0.07$ dan $p=0.19)$. Asupan protein, zat besi, asam folat, dan vitamin B12 kedua kelompok tidak mencukupi kebutuhan seharusnya.

Simpulan: Terdapat perbadaan kadar hemoglobin, asupan protein, dan vitamin B12 antara ibu nifas mutih dan tidak mutih.

Kata Kunci: Mutih, asupan zat gizi, kadar hemoglobin, status anemia, ibu nifas

\section{PENDAHULUAN}

Perilaku pantang makan merupakan hasil budaya masyarakat yang mengalami perubahan terus menerus dan menghasilkan perilaku makan yang salah, sehingga dapat menyebabkan masalah gizi. ${ }^{1}$ Salah satu budaya pantang makan yang dilakukan oleh ibu nifas di Kabupaten Kudus adalah puasa mutih. Ibu nifas hanya mengkonsumsi nasi, tahu, tempe, beberapa jenis sayur dan buah. Menurut kepercayaan warga setempat, tujuan dari puasa mutih tersebut adalah untuk mempercepat penyembuhan luka dan agar bayinya tidak berbau 
amis. Perilaku pantang makan ibu nifas ini dikhawatirkan akan menyebabkan defisiensi protein, zat besi, asam folat, dan vitamin B12. Defisiensi asupan zat gizi merupakan salah satu faktor risiko terjadinya masalah gizi seperti anemia gizi dan kekurangan energi kronis (KEK) pada masa nifas. $^{1}$

Anemia gizi adalah masalah gizi yang sering dialami oleh ibu nifas. Pada masa nifas, terjadi kehilangan darah yang menyebabkan jumlah hemoglobin di dalam tubuh menurun, sehingga menyebabkan sel-sel tubuh tidak cukup mendapatkan pasokan oksigen. Hal tersebut menyebabkan penurunan kualitas hidup, penurunan kemampuan kognitif, ketidakstabilan emosi, serta depresi pada ibu nifas. ${ }^{2}$ Selain disebabkan oleh perdarahan, anemia pada ibu nifas mutih diperburuk karena asupan zat gizi yang rendah. Dampak anemia ringan pada ibu menyusui hanya berpengaruh pada kualitas ASI, dan untuk anemia berat $(<8 \mathrm{mg} / \mathrm{dL})$ akan berpengaruh pada kualitas dan kuantitas ASI. ${ }^{3}$ Berdasarkan data Riskesdas tahun 2013, prevalensi anemia pada ibu hamil yaitu $37,1 \% .^{4}$ Menurut Survei Kesehatan Rumah Tangga (SKRT) tahun 2005, prevalensi anemia pada ibu nifas yaitu sebesar $45,1 \%{ }^{5}$

Kekurangan protein hewani merupakan kondisi yang dapat dialami oleh ibu nifas mutih dan menjadi salah satu faktor risiko terjadinya anemia pada ibu nifas. Protein merupakan makronutrien yang berperan dalam transportasi dan penyimpanan zat besi. Selain itu, penyerapan zat besi di usus halus juga dibantu oleh protein karier. ${ }^{6}$ Jumlah protein yang diserap bergantung dari mutu protein. Mutu protein ditentukan oleh jenis dan proporsi asam amino yang dikandungnya. Protein yang bermutu tinggi berasal dari kelompok protein hewani kecuali gelatin. ${ }^{7,8}$ Selain memiliki bioavailibilitas tinggi, protein hewani seperti daging, ikan, dan unggas bertindak sebagai Meat fish poultry factor (MFP factor) yang berperan dalam meningkatkan penyerapan zat besi nonheme. ${ }^{9}$

Asupan zat besi yang kurang merupakan faktor risiko terjadinya anemia pada ibu nifas yang melakukan mutih. Hal tersebut dikarenakan zat besi merupakan komponen utama dalam pembentukan darah terutama dalam pembentukan molekul hemoglobin. ${ }^{10}$ Ibu nifas yang melakukan mutih tidak mengkonsumsi zat besi heme yang memiliki bioavailability tinggi yang terdapat pada sumber hewani. Zat besi pada pangan hewani tersebut lebih tinggi penyerapannya yaitu $20-30 \%$, sedangkan dari sumber nabati hanya $1-6 \%{ }^{8,10}$

Kekurangan asupan asam folat pada ibu nifas mutih merupakan salah satu faktor risiko terjadinya anemia. Asam folat dibutuhkan untuk pembentukan sel darah merah dan sel darah putih dalam sumsum tulang serta pendewasaannya. ${ }^{11}$ Folat berperan sebagai pembawa karbon tunggal dalam pembentukan heme. Defisiensi folat akan menyebabkan gangguan pematangan inti eritrosit, yang berakibat timbulnya sel darah dengan bentuk dan ukuran yang tidak normal. Folat tidak disimpan dalam tubuh dalam jumlah besar, sehingga perlu mendapatkan pasokan vitamin ini melalui diet untuk memenuhi kebutuhan normal. ${ }^{12}$

Asupan vitamin B12 yang kurang merupakan salah satu faktor risiko terjadinya anemia pada ibu nifas yang melakukan mutih. Vitamin B12 merupakan koenzim pada sintesis metionin, yaitu suatu reaksi dimetilasi untuk pembentukan folat, ${ }^{11}$ sehingga vitamin B12 memiliki fungsi yang berkaitan erat dengan folat. Sumber pangan yang kaya akan vitamin B12 terdapat pada pangan hewani seperti, daging, ikan, dan telur. ${ }^{10}$ Akan tetapi, ibu nifas yang mutih tidak mengkonsumsi sumber hewani tersebut.

Berdasarkan latar belakang di atas, perlu dilakukan penelitian lebih lanjut apakah kebiasaan puasa mutih pada ibu nifas di Kecamatan Gebog, Kabupaten Kudus berhubungan dengan kecukupan asupan protein, zat besi, asam folat, vitamin B12 dan kejadian anemia gizi. Tujuan dari penelitian ini adalah untuk mengetahui perbedaan asupan protein, zat besi, asam folat, vitamin B12 dan kejadian anemia pada ibu nifas yang melakukan puasa mutih dan tidak melakukan puasa mutih di Kecamatan Gebog, Kabupaten Kudus.

\section{METODE PENELITIAN}

Penelitian ini dilaksanakan di Kecamatan Gebog, Kabupaten Kudus pada bulan Juni-Agustus 2015. Penelitian ini termasuk dalam lingkup gizi masyarakat studi observasional dengan desain cross-sectional.

Populasi pada penelitian ini adalah seluruh ibu nifas di Kecamatan Gebog, Kabupaten Kudus. Pengambilan subjek diawali dengan melakukan skrining terhadap seluruh ibu nifas untuk memenuhi kriteria inklusi. Kriteria inklusi pada penelitian ini adalah ibu nifas yang tinggal di wilayah kerja Puskesmas Gebog, tidak sedang menderita infeksi seperti, malaria dan kecacingan, dan tidak mengalami perdarahan patologis pada saat melahirkan. Jumlah sampel minimal adalah 22 subjek untuk masing-masing kelompok. Subjek diambil dengan cara purposive sampling untuk mendapatkan sampel minimal. Akan tetapi, pada pelaksanaannya di lapangan, subjek yang memenuhi kriteria inklusi untuk kelompok mutih 
tidak dapat memenuhi jumlah sampel minimal, sehingga hanya didapatkan 16 subjek untuk masingmasing kelompok. Pemilihan kelompok tidak mutih diambil dengan cara matching by design dan variabel yang di matching yaitu lama perdarahan pervaginal (PPV).

Variabel bebas pada penelitian ini adalah status mutih, sedangkan variabel terikat adalah asupan protein, zat besi, asam folat, dan kejadian anemia. Data yang dikumpulkan pada penelitian ini adalah identitas subjek (usia, pendidikan terakhir, pekerjaan, jumlah anak), berat badan, tinggi badan, lama perdarahan pervaginal (PPV), status mutih, kadar hemoglobin saat hamil dan saat nifas, serta asupan protein, zat besi, asam folat, dan vitamin B12. Data identitas subjek dan PPV diperoleh melalui wawancara langsung menggunakan kuisioner karakteristik subjek. Berat badan dan tinggi badan subjek diperoleh dengan melakukan pengukuran langsung menggunakan alat ukur timbangan digital dan mikrotoa.

Status mutih didefinisikan sebagai perilaku pantang makan ibu nifas yang hanya mengkonsumsi nasi, tempe, tahu, beberapa jenis sayuran, dan buah seperti, kacang panjang, labu siam, wortel, daun katuk, kangkung, jeruk, pisang, dan pepaya. Puasa mutih tersebut dilakukan oleh ibu nifas selama 40 hari. Data status mutih didapatkan berdasarkan pengakuan langsung dari subjek melalui wawancara langsung saat proses skrining.

Asupan protein, zat besi, asam folat, dan vitamin B12 didefinisikan sebagai jumlah asupan protein, zat besi, asam folat, dan vitamin B12 yang bersumber dari makanan yang dikonsumsi seharihari dan diperoleh dengan menggunakan formulir Semiquantitative Food Frequency Questionaire kemudian dihitung menggunakan software nutrisurvey. Kecukupan asupan protein dibandingkan dengan kebutuhan protein seharusnya masing-masing subjek, sedangkan asupan zat besi, asam folat dan vitamin B12 dibandingkan dengan AKG untuk ibu menyusui. Kadar Hemoglobin saat hamil diperoleh dari data sekunder yang terdapat pada buku periksa kehamilan subjek pada trimester
III. Untuk kadar hemoglobin saat nifas diukur dengan menggunakan metode Cyanmethemoglobin. Pengambilan darah dilakukan oleh tenaga ahli secara intravena kemudian dianalisis di Laboratorium di Kudus. Hasil analisis dikategorikan menjadi anemia apabila $\mathrm{Hb}<$ $12 \mathrm{mg} / \mathrm{dl}$ dan normal apabila $\geq 12 \mathrm{mg} / \mathrm{dl}$.

Pengolahan dan analisis data dilakukan dengan program komputer. Analisis univariat dilakukan untuk mendeskripsikan kategori, rerata, standar deviasi, nilai tengah, serta nilai minimal dan maksimal semua variabel yang diambil. Analisis bivariat dilakukan untuk menganalisis perbedaan asupan protein, zat besi, asam folat, vitamin B12, dan kejadian anemia antara kedua kelompok serta menganalisis hubungan asupan protein, zat besi asam folat, dan vitamin B12 dengan kadar hemoglobin saat nifas. Uji independent $t$ test digunakan untuk menganalisis perbedaan kadar hemoglobin saat nifas karena data berdistribusi normal, sedangkan uji Mann Whitney digunakan untuk menganalisis perbedaan asupan protein, zat besi, asam folat, dan vitamin B12 karena data berdistribusi tidak normal. Uji korelasi dengan Rank Spearman untuk menganalisis hubungan asupan protein, zat besi, asam folat, dan vitamin B12 dengan kadar hemoglobin saat nifas.

\section{HASIL PENELITIAN \\ Karakteristik Subjek}

Subjek penelitian berjumlah 32 orang yang terdiri dari $16 \mathrm{ibu}$ nifas melakukan puasa mutih dan 16 ibu nifas tidak melakukan puasa mutih. Lama perdarahan antara kedua kelompok sama yaitu berkisar dari 7 hari hingga 14 hari dengan nilai median 10 hari. Kelompok ibu nifas mutih memiliki kadar Hemoglobin $(\mathrm{Hb})$ saat hamil lebih tinggi daripada yang tidak mutih dengan nilai rerata $11,55 \pm 1.16$. Indeks massa tubuh kelompok ibu nifas mutih lebih rendah dibandingkan dengan kelompok tidak mutih dengan nilai median $21.1 \mathrm{~kg} / \mathrm{m}^{2}$. Akan tetapi, berdasarkan hasil uji beda, tidak terdapat perbedaan kadar $\mathrm{Hb}$ hamil dan indeks massa tubuh antara kedua kelompok.

Tabel 1. Karakteristik Subjek antara kelompok dengan kebiasaan puasa mutih dan tidak mutih

\begin{tabular}{|c|c|c|c|c|c|c|c|c|c|}
\hline \multirow{2}{*}{$\begin{array}{c}\text { Karakteristik } \\
\text { Subjek }\end{array}$} & \multicolumn{4}{|c|}{ Mutih (n=16) } & \multicolumn{4}{|c|}{ Tidak Mutih $(n=16)$} & \multirow[t]{2}{*}{$p$} \\
\hline & Min & Max & Median & Rerata \pm SD & Min & Max & Median & Rerata \pm SD & \\
\hline Usia (tahun) & 20 & 38 & - & $26.88 \pm 5.88$ & 20 & 36 & - & $29.13 \pm 6.01$ & $0.29^{\mathrm{a}}$ \\
\hline Hb hamil (mg/dl) & 10.1 & 13.8 & - & $11.55 \pm 1.16$ & 7.6 & 12.6 & - & $11.05 \pm 1.31$ & $0.22^{\mathrm{a}}$ \\
\hline $\begin{array}{l}\text { Lama } \\
\text { perdarahan/PPV }\end{array}$ & & & & & & & & & $1.00^{\mathrm{b}}$ \\
\hline (hari) & 7 & 14 & 10 & - & 7 & 14 & 10 & - & \\
\hline $\operatorname{IMT}\left(\mathrm{kg} / \mathrm{m}^{2}\right)$ & 17.1 & 31.4 & 21.1 & - & 18.2 & 40.4 & 23.5 & - & $0.16^{\mathrm{b}}$ \\
\hline
\end{tabular}


Makanan yang dikonsumsi oleh kelompok ibu nifas yang melakukan puasa mutih dan tidak mutih

Ibu nifas mutih tidak mengkonsumsi sumber hewani seperti, daging kerbau, daging ayam, telur ayam, ikan lele, dan ikan bandeng dibandingkan dengan kelompok ibu nifas yang tidak mutih. Ibu nifas mutih hanya mengkonsumsi beberapa jenis sayuran dan buah yaitu kacang panjang, labu siam, kangkung, daun katuk, wortel, sawi, pisang, pepaya, dan jeruk. Ibu nifas yang tidak mutih mengkonsumsi sayuran dan buah dengan variasi jenis yang lebih beragam. Akan tetapi, tidak terdapat perbedaan konsumsi tempe dan pepaya antara kedua kelompok. Selain itu, ibu nifas mutih juga mengkonsumsi makanan jajanan seperti kue apem, pukis, coro bikan, dan kripik singkong.

Tabel 2. Perbedaan rata-rata frekuensi konsumsi bahan makanan subjek

\begin{tabular}{|c|c|c|}
\hline \multirow[t]{2}{*}{ Bahan makanan } & \multicolumn{2}{|c|}{ Rata-rata frekuensi konsumsi } \\
\hline & Mutih & Tidak mutih \\
\hline Nasi putih ${ }^{\mathrm{a}}$ & 3,4 & 3,4 \\
\hline Tahu ${ }^{b}$ & 3,9 & 2,1 \\
\hline Tempe $^{\mathrm{b}}$ & 2,8 & 2,4 \\
\hline Daging ayam ${ }^{\mathrm{b}, \mathrm{c}}$ & 0 & 3,3 \\
\hline Ikan lele ${ }^{b, c}$ & 0 & 2,9 \\
\hline Ikan bandeng ${ }^{\mathrm{b}, \mathrm{c}}$ & 0 & 2,6 \\
\hline Daging kerbau ${ }^{\mathrm{b}, \mathrm{c}}$ & 0 & 2,4 \\
\hline Telur ayam ${ }^{\mathrm{b}, \mathrm{c}}$ & 0 & 0,2 \\
\hline labu siam ${ }^{\mathrm{b}}$ & 20,3 & 16,8 \\
\hline Kacang panjang ${ }^{\mathrm{b}}$ & 18,9 & 14,7 \\
\hline Sawi ${ }^{\mathrm{C}}$ & 2,4 & 2,9 \\
\hline Wortel $^{\mathrm{b}}$ & 2,2 & 2,0 \\
\hline Kangkung ${ }^{b}$ & 2,1 & 2,3 \\
\hline Daun katuk ${ }^{\mathrm{b}}$ & 3,8 & 3,3 \\
\hline Bayam $^{\mathrm{b}, \mathrm{c}}$ & 0 & 3,3 \\
\hline Gambas $^{\mathrm{b}, \mathrm{c}}$ & 0 & 3,3 \\
\hline $\mathrm{Kol}^{\mathrm{b}, \mathrm{c}}$ & 0 & 3,2 \\
\hline Daun singkong ${ }^{\mathrm{b}, \mathrm{c}}$ & 0 & 3,1 \\
\hline Terong ${ }^{b, c}$ & 0 & 2,9 \\
\hline Daun pepaya ${ }^{\mathrm{b}, \mathrm{c}}$ & 0 & 2,8 \\
\hline Buncis s,c $^{b}$ & 0 & 2,6 \\
\hline Pepaya $^{\mathrm{b}}$ & 6,3 & 2,1 \\
\hline Nangka muda & 0 & 2,5 \\
\hline Pisang ${ }^{\mathrm{b}}$ & 2,6 & 2,5 \\
\hline Jeruk $^{\mathrm{b}}$ & 2,1 & 2,4 \\
\hline Jambu biji ${ }^{\mathrm{b}, \mathrm{c}}$ & 0 & 3,0 \\
\hline Salak$^{b, c}$ & 0 & 3,0 \\
\hline Semangka ${ }^{\mathrm{b}, \mathrm{c}}$ & 0 & 2,8 \\
\hline Melon $^{\mathrm{b}, \mathrm{c}}$ & 0 & 2,4 \\
\hline Kue apem ${ }^{b}$ & 2,9 & 3,2 \\
\hline Pukis $^{b}$ & 2,7 & 2,9 \\
\hline Kue lapis ${ }^{\mathrm{b}}$ & 2,4 & 3,0 \\
\hline Coro bikan ${ }^{\mathrm{b}}$ & 2,2 & 3,1 \\
\hline Kripik singkongb & 1,2 & 2,8 \\
\hline Donat $^{\mathrm{b}, \mathrm{c}}$ & 0 & 3,0 \\
\hline Bolu b,c & 0 & 2,9 \\
\hline
\end{tabular}

$\mathrm{a}(\mathrm{kali} / \mathrm{hari})$

$\mathrm{b}(\mathrm{kali} /$ minggu $)$

c $\mathrm{P}<0.01$

Perbedaan asupan protein, zat besi, asam folat, dan kejadian anemia pada kelompok ibu nifas mutih dan tidak mutih

Berdasarkan tabel 3, asupan protein kelompok ibu nifas yang mutih lebih rendah dibandingkan dengan kelompok ibu nifas yang tidak mutih dengan median sebesar 31,3 gram. Akan tetapi, kecukupan asupan protein kedua kelompok ibu nifas rendah yang ditunjukkan dengan nilai median $11,3 \%$ dan $16,1 \%$ dari kebutuhan protein seharusnya. Hasil uji komparatif secara statistik menunjukkan bahwa terdapat 
perbedaan bermakna $(p<0.01)$ asupan dan persen kecukupan protein antara kedua kelompok tersebut.

Hasil uji asupan zat besi (tabel 3) diketahui bahwa tidak terdapat perbedaan asupan dan persen kecukupan zat besi antara ibu nifas yang mutih dan yang tidak mutih dengan nilai $p=0,07$. Hasil perhitungan kecukupan asupan zat besi pada kedua kelompok tersebut seluruhnya rendah yaitu hanya terpenuhi 24,69\% untuk kelompok mutih dan $31,1 \%$ untuk kelompok tidak mutih.

Asupan dan persen kecukupan asam folat antara kedua kelompok ibu nifas pada tabel 3 secara statistik menunjukkan tidak tedapat perbedaan yang bermakna $(p<0.19)$. Kecukupan asupan asam folat semua kelompok rendah yaitu hanya mencapai $34,4 \%$ untuk kelompok mutih dan $38,6 \%$ untuk kelompok tidak mutih.

Tabel 3. Perbedaan asupan zat gizi dan kadar hemoglobin saat nifas antara kelompok ibu nifas mutih dan tidak mutih

\begin{tabular}{|c|c|c|c|c|c|c|c|c|c|}
\hline \multirow{2}{*}{$\begin{array}{c}\text { Karakteristik } \\
\text { Subjek }\end{array}$} & \multicolumn{4}{|c|}{ Mutih (n=16) } & \multicolumn{4}{|c|}{ Tidak Mutih(n=16) } & \multirow[b]{2}{*}{$p$} \\
\hline & Min & Max & Median & Rerata \pm SD & Min & Max & Median & Rerata \pm SD & \\
\hline \multicolumn{10}{|l|}{ Asupan } \\
\hline Protein (gram) & 19 & 50.2 & 31.3 & - & 29.9 & 84.9 & 46.5 & - & $0.01^{\mathrm{a}}$ \\
\hline Zat besi (mg) & 5.20 & 22.4 & 7.9 & - & 6.2 & 18.2 & 9.9 & - & $0.07^{\mathrm{a}}$ \\
\hline Asam folat (mcg) & 68.1 & 292.2 & 172.2 & - & 94.2 & 447.6 & 192.8 & - & $0.19^{\mathrm{a}}$ \\
\hline $\begin{array}{l}\text { Vitamin B12 } \\
(\mathrm{mcg})\end{array}$ & 0 & 0.3 & 0.1 & - & 0.4 & 7.9 & 1.9 & - & $0.01^{\mathrm{a}}$ \\
\hline \multicolumn{10}{|l|}{$\begin{array}{l}\text { Kecukupan } \\
\text { asupan }\end{array}$} \\
\hline Protein $(\%)$ & 7.4 & 18.9 & 11.3 & - & 10.1 & 26.3 & 16.1 & - & $0.01^{\mathrm{a}}$ \\
\hline Zat besi (\%) & 16.3 & 70 & 24.7 & - & 19.4 & 56.9 & 31.1 & - & $0.07^{\mathrm{a}}$ \\
\hline Asam folat $(\%)$ & 13.6 & 58.4 & 34.4 & - & 18.8 & 89.5 & 38.6 & - & $0.19^{\mathrm{a}}$ \\
\hline Vitamin B12 (\%) & 0 & 10.7 & 3.6 & - & 14.3 & 282.1 & 66.1 & - & $0.01^{\mathrm{a}}$ \\
\hline Hb nifas (mg/dl) & 9.8 & 12.2 & - & $11.02 \pm 0.76$ & 11.2 & 14.5 & - & $12.51 \pm 0.79$ & $0.01^{\mathrm{b}}$ \\
\hline
\end{tabular}

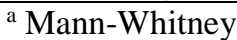

bindependent t-test

Uji perbedaan asupan dan persen kecukupan vitamin B12 antara kelompok ibu nifas mutih dan tidak mutih menunjukkan perbedaan yang bermakna dengan nilai $p<0.01$. Kecukupan asupan vitamin B12 pada kelompok ibu nifas mutih rendah yaitu hanya mencapai $3,6 \%$, sedangkan pada kelompok ibu nifas yang tidak mutih mencapai $66,1 \%$ dari AKG yang dianjurkan.
Hasil uji komparatif kadar $\mathrm{Hb}$ nifas pada tabel 3 menunjukkan bahwa terdapat perbedaan antara kadar $\mathrm{Hb}$ ibu nifas mutih dan tidak mutih. Terdapat perbedaan status anemia antara kedua kelompok (tabel 4), pada kelompok ibu nifas mutih lebih banyak mengalami anemia yaitu sebanyak 15 orang $(93,7 \%)$ daripada kelompok ibu nifas yang tidak mutih yaitu hanya terdapat 4 orang $(25 \%)$ yang mengalami anemia.

Tabel 4. Perbedaan status anemia berdasarkan status mutih subjek

\begin{tabular}{|c|c|c|c|c|c|c|}
\hline & & \multicolumn{4}{|c|}{ Status Mutih } & \multirow{3}{*}{$p$} \\
\hline & & \multicolumn{2}{|c|}{ Mutih } & \multicolumn{2}{|c|}{ Tidak mutih } & \\
\hline & & $\mathbf{n}$ & $\%$ & $\mathbf{n}$ & $\%$ & \\
\hline \multirow[t]{2}{*}{ Status anemia } & Anemia & 15 & 93,7 & 4 & 25 & $0.01^{\mathrm{a}}$ \\
\hline & Normal & 1 & 6,3 & 12 & 75 & \\
\hline
\end{tabular}

${ }^{\mathrm{a} C h i}$ square

\section{Hubungan asupan zat gizi dengan kadar hemoglobin saat nifas}

Hasil uji korelasi pada tabel 5 menunjukkan bahwa terdapat hubungan yang signifikan antara asupan protein $(\mathrm{r}=0.68, p<0.01)$ dan vitamin $\mathrm{B} 12$ $(\mathrm{r}=056, p<0.01)$ dengan kadar hemoglobin saat nifas subjek. Adanya korelasi positif menunjukkan semakin baik asupan protein dan vitamin B12 maka kadar hemoglobin saat nifas akan naik. Namun, pada asupan zat besi dan asam folat menunjukkan tidak terdapat hubungan yang signifikan dengan kadar hemoglobin saat nifas subjek $(\mathrm{r}=0.27, p=0.14$ dan $\mathrm{r}=0.24, \quad p=0.19)$. Korelasi positif juga ditunjukkan dari hasil uji korelasi tersebut. 
Tabel 5. Hubungan asupan zat gizi dengan kadar hemoglobin pada saat nifas

\begin{tabular}{lcc}
\multicolumn{1}{c}{ Variabel } & \multicolumn{2}{c}{ Kadar hemoglobin saat nifas } \\
\cline { 2 - 3 } & $\mathbf{r}$ & $\boldsymbol{p}$ \\
Asupan protein & 0.56 & $0.01^{\mathrm{a}}$ \\
Asupan zat besi & 0.27 & $0.14^{\mathrm{a}}$ \\
Asupan asam folat & 0.24 & $0.19^{\mathrm{a}}$ \\
Asupan vitamin B12 & 0.68 & $0.01^{\mathrm{a}}$ \\
\cline { 2 - 3 } & &
\end{tabular}

${ }^{a}$ Rank Spearman

\section{PEMBAHASAN}

Mutih merupakan salah satu budaya pantang makan yang telah turun temurun yang dilakukan oleh ibu nifas di Kabupaten Kudus yang saat ini telah mengalami pergeseran yang menonjol. Pada awal ditetapkan mutih ini ibu nifas hanya diperbolehkan makan nasi dengan uyah songo atau garam yang disangrai di atas tungku kayu, kemudian bergeser menjadi memperbolehkan makan tahu dan tempe, dan sekarang boleh ditambah mengkonsumsi beberapa jenis sayur dan buah. Pantangan terhadap makanan tertentu merupakan perilaku yang berkaitan dengan masalah gizi. Masyarakat tidak mengerti kapan suatu pantang makanan dimulai, apa sebabnya, dan seringkali nilai sosial ini tidak sesuai dengan konsep dasar ilmu gizi dan kesehatan. ${ }^{13}$

Angka kejadian anemia pada ibu nifas mutih lebih tinggi yaitu sebesar $93,7 \%$ sedangkan pada ibu nifas tidak mutih sebesar $25 \%$. Berdasarkan hasil uji beda kadar hemoglobin saat hamil kedua kelompok tidak menunjukkan perbedaan yang bermakna. Akan tetapi, hasil uji perbedaan kadar hemoglobin saat nifas menunjukkan bahwa terdapat perbedaan signifikan antara ibu nifas mutih dan ibu nifas tidak mutih setelah dilakukan matching terhadap lama perdarahan pervaginal (PPV). Anemia pada ibu nifas mutih tersebut berkaitan dengan asupan zat gizi. Uji satistik menunjukkan bahwa terdapat hubungan bermakna status mutih dengan status anemia subjek. Budaya mutih ini menyebabkan rendahnya asupan zat gizi pada ibu nifas, sehingga dapat menjadi faktor risiko terjadinya anemia gizi. Anemia yang mungkin terjadi pada ibu nifas mutih yaitu anemia megaloblastik. Akan tetapi, tidak menutup kemungkinan terjadi anemia defisiensi zat besi. Hal tersebut dikarenakan jumlah asupan zat besi subjek tidak mencukupi kebutuhan seharusnya.

Pada penelitian ini menunjukkan terdapat perbedaan asupan protein antara ibu nifas mutih dan ibu nifas tidak mutih. Hal ini disebabkan karena ibu nifas mutih lebih sering mengkonsumsi protein nabati dan tidak mengkonsumsi protein hewani seperti ibu nifas tidak mutih. Perbedaan asupan protein kelompok mutih dan tidak mutih berhubungan signifikan dengan kadar hemoglobin.
Protein memiliki peran penting pada absorbsi dan transportasi besi, terutama untuk protein hewani. Protein hewani memiliki nilai biologis tinggi serta berperan dalam meningkatkan penyerapan zat besi nonheme. Protein ini harus dipenuhi dalam jumlah yang cukup agar sintesis hemoglobin berjalan dengan baik. ${ }^{9,14}$ Hasil penelitian ini sejalan dengan penelitian observasional pada 64 wanita usia subur di Biringkanaya Makasar yang menyatakan bahwa asupan protein hewani memiliki hubungan yang signifikan dengan kadar hemoglobin. ${ }^{15}$

Hasil analisis asupan zat besi secara statistik menunjukkan bahwa tidak terdapat perbedaan yang bermakna antara kedua kelompok. Hal tersebut disebabkan karena pada kelompok mutih konsumsi zat besi berasal dari tempe, tahu, dan sayuran hijau, yang memiliki bioavailibilitas rendah. ${ }^{6,8}$ Dan pada kelompok tidak mutih, konsumsi zat besi berasal dari ikan lele, ikan bandeng, telur ayam, daging ayam, dan sayuran hijau yang hanya mengandung sedikit zat besi, sehingga hasil perhitungan total asupan zat besi kedua kelompok tidak berbeda signifikan. Kebiasaan makan ibu nifas mutih ini menyerupai dengan pola konsumsi vegetarian vegan. Hasil penelitian ini sejalan dengan penelitian Miftahul pada tahun 2011 yang menunjukkan bahwa tidak terdapat perbedaan asupan besi antara vegetarian nonvegan dan vegan. ${ }^{16}$

Hasil uji korelasi asupan zat besi dengan kadar hemoglobin saat nifas menunjukkan bahwa tidak terdapat hubungan yang signifikan. Hasil penelitian ini dapat disebabkan karena sumber zat besi yang dikonsumsi oleh kelompok mutih adalah zat besi nonheme. Penyerapan zat besi nonheme ditentukan oleh status besi seseorang dan jumlah zat besi yang terdapat pada keseluruhan diet. ${ }^{9,10}$ Kelompok tidak mutih mengkonsumsi makanan yang mengandung sedikit sumber besi heme serta ditambah dengan banyak mengkonsumsi sumber fitat dan oksalat sebagai penghambat penyerapan zat besi. ${ }^{17}$ Selain itu, subjek juga minum teh setelah makan dengan frekuensi rata-rata dua kali sehari. Beberapa penelitian menunjukkan bahwa konsumsi teh berlebih dapat mempengaruhi proses penyerapan zat besi nonheme dalam tubuh. Kandungan tanin dalam teh diketahui membentuk 
ikatan larut dengan molekul besi nonheme sehingga mencegah penyerapan besi nonheme dalam tubuh. ${ }^{17}$

Hasil penelitian ini menunjukkan bahwa tidak terdapat perbedaan bermakna asupan asam folat antara ibu nifas mutih dan tidak mutih. Hasil penelitian ini juga menunjukkan tidak terdapat hubungan yang signifikan asupan asam folat dan kadar hemoglobin. Berdasarkan pengkajian asupan asam folat diketahui bahwa sumber asupan asam folat kedua kelompok ibu nifas lebih banyak berasal dari sayuran. Kedua kelompok ibu nifas mengkonsumsi sayuran hijau dalam jumlah dan frekuensi yang kecil, sedangkan kebutuhan asam folat pada ibu nifas meningkat. Tidak adanya hubungan asupan asam folat dan kadar hemoglobin berkaitan dengan bioavailibilitas dari asam folat tersebut. Bioavailibilitas rendah dapat disebabkan oleh bentuk tidak larut pada jenis makanan tertentu, kerusakan tetrahidrofolat saat melewati lambung, hambatan dekonjugasi folat dari poliglutamil oleh unsur makanan, dan penurunan dekonjugasi folat karena $\mathrm{pH}$ usus. ${ }^{18}$

Asupan vitamin B12 pada ibu nifas yang mutih dan tidak mutih juga berbeda bermakna. Hal ini dikarenakan kelompok ibu nifas mutih mendapat asupan vitamin B12 dari sumber nabati dan tidak mengkonsumsi sumber hewani, seperti daging, ikan, ayam, dan telur, sedangkan sumber vitamin B12 banyak terdapat pada sumber pangan hewani yang diperoleh dari hasil sintesis bakteri di dalam usus, seperti hati, telur, ikan, dan daging. ${ }^{9}$ Asupan vitamin B12 tersebut berhubungan signifikan dengan kadar hemoglobin subjek. Vitamin B12 ini memiliki peranan yang sangat penting dalam meningkatkan pembentukan dan pematangan sel darah merah. Defisiensi vitamin B12 dapat menyebabkan kegagalan pematangan dalam proses eritropoiesis. ${ }^{9,10}$ Hasil penelitian ini sejalan dengan penelitian oleh Triwidyastuty pada tahun 2011 yang menunjukkan terdapat hubungan yang signifikan antara asupan vitamin B12 dengan status hemoglobin pada ibu hamil di kabupaten Takalar. ${ }^{19}$

\section{SIMPULAN}

Kejadian anemia pada ibu nifas mutih tinggi yaitu sebesar 93,7\%, sedangkan pada kelompok ibu nifas tidak mutih sebesar $25 \%$. Terdapat perbedaan kejadian anemia antara ibu nifas mutih dan tidak mutih. Asupan protein, zat besi, asam folat, dan vitamin B12 baik pada kelompok ibu nifas mutih maupun ibu nifas tidak mutih tidak mencukupi kebutuhan seharusnya. Terdapat perbedaan yang bermakna asupan protein dan vitamin B12 antara kelompok ibu nifas mutih dan ibu nifas tidak mutih.

\section{SARAN}

Perlu dilakukan pendekatan personal kepada kedua kelompok ibu nifas untuk memberikan edukasi dan konseling. Hal tersebut dikarenakan baik pada kelompok ibu nifas mutih maupun tidak mutih asupan zat gizi tergolong rendah. Pada ibu nifas mutih, edukasi dan konseling bertujuan untuk merubah perilaku pantang makan, sedangkan pada ibu nifas tidak mutih edukasi dan konseling dilakukan untuk meningkatkan jumlah dan variasi jenis asupan zat gizi.

Perlu dilakukan uji morfologi sel darah merah subjek. Hal ini bertujuan untuk mengetahui gambaran morfologi dari eritstrosit subjek, sehingga dapat menentukan secara pasti jenis anemia yang terjadi pada kedua kelompok ibu nifas.

\section{DAFTAR PUSTAKA}

1. Nurhikmah. Hubungan Perilaku Ibu Berpantang Makanan Selama Masa Nifas dengan Status Gizi Ibu dan Bayinya di Kecamatan Banjarmasin Utara di Kota Banjarmasin [Tesis]. Yogyakarta: Universitas Gajahmada; 2009.

2. Milman N. Postpartum anemia I: definition, prevalence, causes, and consequences. Ann Hematol 2011;90:1247-1253.

3. Ayu W. Hubungan Anemia dalam Kehamilan dengan Perdarahan Postpartum Karena Atonia Uteri di RSUD Wonogiri [Skripsi]. Surakarta: Universitas Sebelas Maret; 2010.

4. Kementrian Kesehatan RI. Riset Kesehatan Dasar: Riskesdas 2013. Jakarta: Kementrian Kesehatan RI; 2013.

5. Kementrian Kesehatan RI. Survei Kesehatan Rumah Tangga: SKRT 2005. Jakarta: Kementrian Kesehatan RI; 2005.

6. Arisman MB. Gizi Dalam Daur Kehidupan. Jakarta: EGC; 2010.

7. Soekirman. Ilmu Gizi dan Aplikasinya untuk Keluarga dan Masyarakat. Jakarta: Dirjen Perguruan Tinggi Departemen Pendidikan Nasional; 2000

8. Nisreen A, Darren CG, Nigel ABS, Harry JM, Keith MG, Janet EC. Dietary Iron Intake During Early pregnancy and Birth Outcomes in British in a Cohort of British Women. Human Reproduction 2011;26(4):911-919.

9. Whitney E, Rolfes SR. Understanding nutrition, 11th ed. USA: Thomson Wadsworth; 2008.p.1956,342,443-9.

10. Anderson JJB. Minerals. In: Mahan LK, Stumps SE, editors. Krause's food, nutrition, and diet therapy. 11th ed. Philadelphia: Saunders; 2004.p.135-48.

11. Guyton AC, Hall JE. Buku Ajar Fisiologi Kedokteran [Irawati, Ramadani D, Indriyani F]. 
Edisi 11. Jakarta: Penerbit Buku Kedokteran EGC; 2006.

12. Combs GF. The Vitamin-Fundamental aspect in Nutrition and Health second edition. London: academic Press; 1992.

13. Setiya H. Hubungan Perilaku Pantang Makanan dengan Lama Penyembuhan Luka Perineum pada Ibu Nifas di Kecamatan Srengat Kabupaten Blitar [Skripsi]. Surakarta: Universitas Sebelas Maret; 2010.

14. Mitchell MK. Nutrition across the life span. 2nd ed. Philadelphia: Saunders; 2003. p.533.

15. Kurniati, Thaha AR, Jafar N. Hubungan asupan zat gizi dengan kejadian anemia pada wanita prakonsepsi di kecamatan Bringkanaya Kota Makasar. Universitas Hasanudin; 2013.

16. Miftahul J. Perbedaan Asupan Zat Gizi dan Nongizi yang Berkaitan dengan Kadar Hemoglobin Vegetarian Vegan dan Nonvegan [Skripsi]. Semarang. Universitas Diponegoro; 2011.

17. Zijp IM, Korver SN. Effect of Tea and Other Dietary Factors on Iron Absorpsion. Crit Rev Food Sci Nutr 2000 Sep;40(5):371-98. Review

18. Martha HS, Marie AC. Biochemical, Physiological, and Molecular Aspect of Human Nutrition. 3rd ed. US: Saunders; 2013.p.567.

19. Triwidyastuty D. Faktor-Faktor Yang Berhubungan dengan Status Hemoglobin Ibu Hamil di Kelurahan Manongkoki, Kecamatan Polongbangkeng Utara, Kabupaten Takalar [Skripsi]. Makassar: Universitas Hasanuddin; 2011. 